\title{
Complete polydactylism in Papua New Guinea village pig, with otocephalic homozygous monsters
}

\author{
G.L. MALYNICZ \\ Department of Primary Industry \\ P.O. Box 2417, Konedobu, Papua New-Guinea
}

\begin{abstract}
Summary
A condition of polydactylism consisting of one or more medial super-numery digits on all four legs is described in indigenous pig of Papua New-Guinea. The inheritance is suggested to be monofactorial autosomal dominant. In the heterozygote a polydactyl pig results which is clinically normal in every other respect. In the homozygote a lethal monster results which if born has clubbed feet and grossly deformed skull. Four out of five monsters had an elephant like proboscis. The proposed symbol is $P y^{p}: P y$ for Polydactyly and $p$ for papuan.
\end{abstract}

The presence of polydactyly in the native pig population of Papua New Guinea was noted by the author in 1970 . The frequency of the condition appears to be higher in the Simbu Province where in one area 5 p. 100 of the pigs were reported by the village people to have the condition.

A small herd of two boars and four sows was based at the Tropical Pig Breeding and Research Centre of Goroka (Eastern Highlands Province) from 1971 to 1973. A higher incidence of lameness was noted in the polydactyl pigs. During the course of the breeding programme three types of progeny resulted : normal, polydactyl and monsters.

On figure 1 ( $a$ and $b$ ) are shown respectively a typical polydactyl foot and a preparation of the anterior foot bones. The supernumery digit results from a splitting of the second phalanx. The articulation of the supernumery digit with the carpus or tarsus is much smaller than that of the other normal digits. All cases studied were found to be quite similar although in a small number of cases there were two supernumery digits. This material has been referred to by NEAL et al. (1975).

Four out of live of the monsters resulting from polydactyl $\times$ polydactyl matings were similar with an elephant like proboscis, while the fifth had a unique cranial structure with the whole of the skull anterior to the ears missing. A radiograph of a 

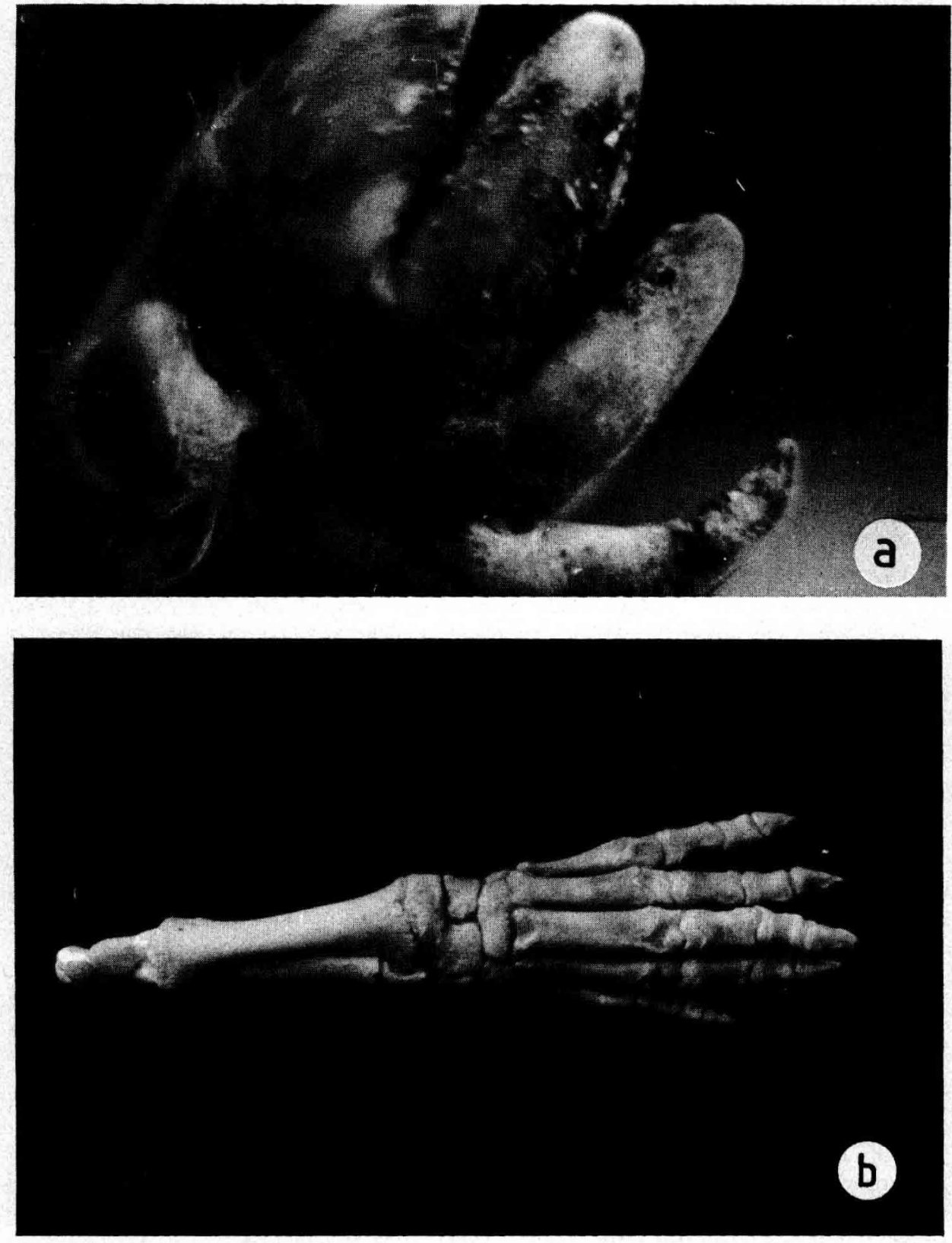

FIG. 1

a) A typical case of polydactyly (heterozygous stage). Cas typique de polydactylie (chez l'hétérozygote).

b) A preparation of a polydactyl fore-foot. Preparation d'un pied avant polydactyle. 

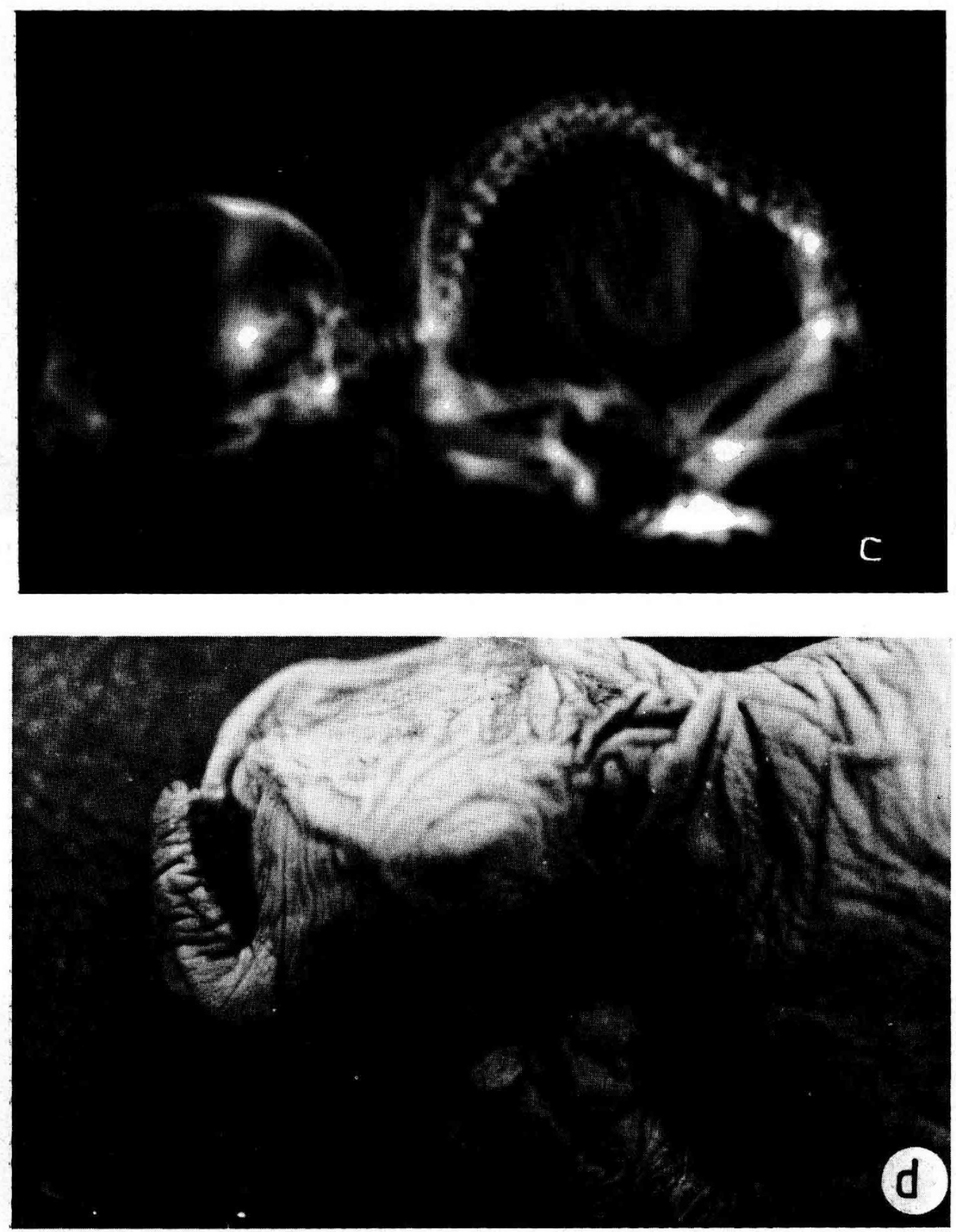

c) Radiograph of a homozygous monster. Radiographie d'un monstre homozygote.

d) Head and fore feet of a homozygous monster. Tête et pied avant d'un monstre homozygote. 
typical case is shown in figure $1 \mathrm{c}$ and figure $1 \mathrm{~d}$ shows a detail of the face of a typical case. In one case a central cyclopian eye was present.

Three types of mating were set up :

a) Polydactyl $\times$ Polydactyl ;

b) Polydactyl $\times$ Normal ;

c) Normal offspring from polydactyl matings $\times$ Normal.

The numbers of each mating and the results obtained are shown in table 1 . The simplest hypothesis accounting for the observed ratios is that Polydactyly results from a dominant factor which, when homozygous produces lethal monsters. The number of monsters recovered at birth was somewhat below that predicted by the hypothesis and it could be assumed that a proportion of foetal monsters die in utero and are absorbed. A chi square analysis however was consistant with the hypothesis of a $1: 2: 1$ segregating ratio at birth.

TABLE 1

The results mating of polydactyl and normal pigs.

Résultats de croisements entre porcs normaux et polydactyles.

\begin{tabular}{|c|c|c|c|c|c|c|c|c|}
\hline \multirow{3}{*}{ Mating } & \multirow{3}{*}{$\begin{array}{c}\text { Number } \\
\text { of } \\
\text { matings }\end{array}$} & \multicolumn{6}{|c|}{ Offspring } & \multirow{3}{*}{$\chi^{2}$} \\
\hline & & \multicolumn{2}{|c|}{ Normal } & \multicolumn{2}{|c|}{ Polydactyl } & \multicolumn{2}{|c|}{ Monster } & \\
\hline & & Obs. & Exp. & Obs. & Exp. & Obs. & Exp. & \\
\hline Polydactyl $\times$ polydactyl & 6 & 12 & 10.75 & 26 & 21.5 & 5 & 10.75 & 4.16 N.S. (1) \\
\hline Polydactyl $\times$ normal & 5 & 16 & 15 & 14 & 15 & 0 & 0 & 0.13 N.S. \\
\hline Normal $\times$ normal $\ldots$. & 4 & 25 & 25 & 0 & 0 & 0 & 0 & 0.13 N.S. \\
\hline
\end{tabular}

(1) N.S. : non significant at the 5 p. 100 level.

A number of authors have described polydactylism in the forefeet of the pig : Bateson (1894), Meineis (1922), Curson (1931), Schotterer (1933), Hughès (1934), VAN DeR Walt \& Boom (1934), Кoch, Fischer \& Schumann (1957), FrechKop (1961) and PTAK (1963).

Only three authors, Kalugin (1925), GaedtKe (1959) and Malingiewicz (1948) have reported the condition in all four feet. The specimens studied by KaLUGIN included cases of anterior and posterior polydactylism. The reports of GAEDTKE \& MALINGIEWICZ refer to only single specimens.

KaLUGIN (1925) carried out breeding trials aimed at demonstrating the inheritance of the condition as he found it. The results are difficult to interpret because complete and anterior polydactyls were mated. It was concluded however the condi- 
tion was a mendelian dominant. HugHes (1935) bred cases of anterior polydactylism with inconclusive results.

In all cases described in the pig the extra digits have resulted from a proliferation of the second phalanx into one and occasionally more digits. In no case have the occurence of monsters been associated with the condition in the pig. This suggests that the condition in Papua New Guinea is a different mutant from that described by previous authors.

Polydactylism has also been reported in many other species including the Guinea pig (Wricht, 1934), the Hen (Punnett \& Pense, 1929) and Man (Broman, 1911). In the Guinea pig WRIGHT has suggested that the condition when homozygous produces polydactyl monsters. ScotT (1938) examined the monsters from WrIGHT's experiments and found them to be characterised by clubbeb feet, microphtalmia, enlargement of the diencephalon, missing tibia and abnormalities of organ systems. In the Guinea pig and the Fowl the condition was considered to be caused by more than one inherited factor. It would appear therefore that the condition reported have may be similar to that in the Guinea pig and that due to its severity is probably of recent origin.

A tentative symbol may be proposed for that autosomal mutant : $P y^{p}, P y$ for Polydactyl and $p$ for papuan.

Received for publication in june 1982.

\section{Résumé}

\section{Polydactylie héréditaire complète avec homozygotes otocéphales monstrueux chez le porc villageois de Papouasie Nouvelle-Guinée}

Un type de polydactylie avec un ou plusieurs doigts surnuméraires situés en position médiane à tous les quatre membres est décrit chez le porc villageois de Papouasie NouvelleGuinée. L'anomalie semble monofactorielle dominante. L'hétérozygote polydactyle semble normal par ailleurs. L'homozygote, par contre, est un monstre létal avec pieds en massue et crâne grossièrement déformé. Quatre des cinq monstres examinés avaient une trompe comme celle d'un éléphant. Le symbole proposé pour ce gène est $P y^{p}: P y$ pour $P$ olydactyly, $p$ pour papuan.

\section{References}

BAtESON W., 1894. Materials for the study of variation treated with Special regard to discontinuity in the origin of species. Macmillan, London.

Broman I., 1911. Normale und abnormale Entwicklung des Menschen. J.F. Bergmann, Wiesbaden (quoted by Punnett \& Pease).

Curson H.H., 1931. Polydactyly in a Springbok and a Pig. 17th Report. Dir. Vet. Serv. R.S.A., Pretoria, 853-856.

FrechKop S., 1961. Doigts surnuméraires dans les extrémités antérieures d'un sanglier et d'un porc. Bull. Instit. royal. Sc. nat., Belgique, 37, 1-16.

GaedtKe H. (VON), 1959. Hereditäre Polydaktylie einer Schweinefamilie, Monatsh. Veterinärnied., 14, 57-58.

Hughes E.H., 1935. Polydactyly in Swine. J. Hered., 26, 415-418. 
Kalugin I.I., 1925. Contributions to the study of tri and polydacylous pigs in White Russia. Bull White Russia State Inst. Agric. For., $\mathrm{n}^{\circ} 5,30$ p.; $\mathrm{n}^{\circ} 7,65$ p. ; ${ }^{\circ} 8,53$ p., quoted by Buchanan-Smith, Robinson \& BRyant, in : Genetics of the Pig, Univ. of Edinburgh, 1935.

Koсh P., Fisher H., Schuman H., 1957. Erbpathologie der landwirtschaftlichen Haustiere. Paul Parley, Berlin, 160-162.

Malingiewicz C., 1948. Polydactylism in all four limbs in a swine. Med. vet., 4, 553-554.

Meines F., 1922. Sieben Fälle von Polydactylie beim Schwein. Med., Vet. Diss., Berlin.

Niel F.C., Ramsey F.K., Preston K.S., 1975. In : Dunne \& Leman, Diseases of swine, 4th Edition, Iowa Univ. Press, Ames, Iowa.

PTAK W., 1963. Polydactyly in Wild Boar. Acta Theriol., 7, 312-314.

Punnett R.C., Pease M.S., 1929. Genetic Studies on poultry. VII - Notes on polydactyly. J. Genet., 21, 341-366.

SCHOtTerer A., 1933. Polydactylie und Gaumenspalte bei deutschen Edelschweinen. Z. Tierz. Züchtbiol., 26, 219-223.

ScotT J.P., 1938. The polydacylous monster, a new teras produced by the genes Px Px. J. Morphol., 62, 299-321.

VAN Der Walt S.J., DE Boom H.P.A., 1935. Polydactylism in the pig. Anatonomical Studies, $\mathrm{n}^{\circ}$ 42. Ondestpoort J. Vet. Sci., Ind., 3, 237-238.

Wright S., 1934. A mutation of the Guinea Pig tending to restore the pentadactyl foot when heterozygous producing a monstrosity when homozygous. Genetics, 20, 84-107. 